\title{
Screening Chemical Composition and Bioactive Properties of Mentha $x$ piperita L. Essential Oil and Extract
}

\author{
İlkin Yücel Şengünn ${ }^{1, a, *}$ Ersin Yücel ${ }^{2, b}$, Gülden Kılıçc,c, Berna Öztürk ${ }^{1, d}$ \\ ${ }^{1}$ Food Engineering Department, Engineering Faculty, Ege University, 35040 Izmir, Turkey \\ ${ }^{2}$ Biology Department, Science Faculty, Eskisehir Technical University, 26000 Eskisehir, Turkey
}

*Corresponding author

\section{A R T I C L E I N F O A B S T R A C T}

Research Article

In recent years, medicinal and aromatic herbs, which contain variety of antimicrobial compounds and have no risk to human health in terms of antibiotic resistance, are increasingly used as alternatives to antibiotics. In the study, chemical composition, total phenolic content, antioxidant and antimicrobial activity of essential oil and extract of Mentha x piperita L. growing wild in Eskisehir were investigated. Carvone (55.8\%), limonene (12.8\%), 1.8-cineole $(8.7 \%)$ and transdihydrocarvone $(6.4 \%)$ were determined as the main constituents of the essential oil, while the major components of the extract were carvone (56.4\%), 1.8-cineole (14.1\%) and transdihydrocarvone $(8.4 \%)$. The total phenolic contents of essential oil $(2204.33 \mu \mathrm{g} \mathrm{GAE} / \mathrm{g})$ were significantly higher than of extract ( $744 \mu \mathrm{g} \mathrm{GAE} / \mathrm{g})$. The essential oil and the extract were inhibited $84.08 \%$ and $42.59 \%$ by the DPPH radical, $91.87 \%$ and $48.40 \%$ by the ABTS radical, respectively. The highest inhibition zone was observed against $S$. aureus $(23 \mathrm{~mm})$. However, minimum inhibition concentration (MIC) values of the essential oil were ranged between $2.5 \%$ and $10 \%(\mathrm{v} / \mathrm{v})$, while MIC values of the extract were determined as $10 \%$ and $>10 \%(\mathrm{v} / \mathrm{v})$. The present study demonstrated

Antibacterial activity Antioxidant activity Peppermint

Total phenolic content Chemical composition

that M. piperita could be used in pharmaceutical and food applications as a natural antioxidant and antimicrobial substance.

\section{Introduction}

In recent years, consuming products with plant components providing natural antimicrobial effects has been increased by the awareness of consumers about healthy nutrition (Tajkarimi et al., 2010; Gyawali and Ibrahim, 2014; Calo et al., 2015; Sevindik et al., 2017). Plants are rich sources of phenolic compounds that have been reported to demonstrate high antioxidant activity (Hinneburg et al., 2006; Uribe et al., 2016; Mohammed et al., 2020). Plants contain natural compounds having antioxidant and antimicrobial effects such as saponins, alkaloids, coumarins, flavonoids, organic acids, phenolics, phytochemicals, terpenoids and thiosulfinates (Cowan, 1999; Tajkarimi et al., 2010; Gyawali and Ibrahim, 2014; Mohammed et al., 2021). The antimicrobial activity of these compounds varies depending on many factors, especially with their chemical structures and concentrations (Lai and Roy, 2004; Tiwari et al., 2009; Hayek et al., 2013; Pehlivan et al., 2021). Most of the current studies on plant origin antimicrobials have been focused on the antimicrobial or antioxidant effects of essential oils, extracts and their compounds (Boskovic et al., 2015; El-Maati et al., 2016; Reyes-Munguía et al., 2016; Rodriguez-Garcia et al., 2016; Zhang et al., 2016; Wafa et al., 2017; Mohammed et al., 2019).

Plant extracts and essential oils, which are effective in the formation of unique flavor and color, have been used in food industry, pharmaceutics, cosmetics and perfumery since ancient times (Hadian et al., 2012; Inan et al., 2012; Shiwakoti et al., 2016). Essential oils and extracts obtained from parts of the plants such as stem, leaf, bud, fruit, flower, and seed have antimicrobial effects on many microorganisms (Tajkarimi et al., 2010; Jayasena and Jo, 2013; Gyawali and Ibrahim, 2014; Calo et al., 2015). Besides, the presence of the hydroxyl groups in the phenolic compounds (caffeic acid, chlorogenic acid, $p$ coumaric acid, ferulic acid-7-o-glycoside, gallic acid, rosmarinic acid, etc.) contributes to their antioxidant and 
antimicrobial properties (Cueva et al., 2010; Gyawali and Ibrahim, 2014).

Mentha is an important medicinal plant which belongs to Lamiaceae family with approximately 240 genera and 7200 species (Trevisan et al., 2017; Chagas et al., 2020). Mentha $x$ piperita L. (peppermint), widely grown in Europe, Asia and America, is a plant commonly used worldwide (Tsai et al., 2013; de Sousa Barros et al., 2015; Uribe et al., 2016). It has been reported that peppermint has active ingredients such as caffeic acid, carotenes, flavonoids, polymerized polyphenols, tocopherols, tannins, betaine and choline (Sokovic et al., 2009). The essential oil of peppermint, which is reported to have antimicrobial activity against various microorganisms, is frequently used in the food, pharmaceutical and cosmetic industries. Besides, Yucel and Yucel (2019) reported that peppermint could be used as natural cleaning agent for the industrial wastes. Its leaf is commonly used as a therapeutic agent for cold, inflammation of the mouth, cramps, diarrhea, flatulence, nausea and vomiting (Trevisan et al., 2017). On the other hand, M. piperita has positive effects on human health such as antibacterial, antifungal, antiviral, antidiabetic, antispasmodic, antiulcer, anti-inflammatory, mildly anesthetic, anticancer, antimutagenic, cytoprotective, hypoallergenic, immunomodulatory and hepatoprotective effects (Shah and D'Mello, 2004; Grigoleit and Grigoleit, 2005; Bakkali et al., 2008; Raut and Karuppayil, 2014; Singh et al., 2015).

In the literature, there are many studies examining total phenolic contents, antioxidant and antimicrobial activity of M. piperita, grown in different geographical locations (Iscan et al., 2002; Yadegarinia et al., 2006; Kizil et al., 2010; Sujana et al., 2013; Singh et al., 2015; Zaidi and Dahiya, 2015; Okmen et al., 2017; Chagas et al., 2020). However, to the best of the knowledge of authors, there is no study investigating the bioactive properties of $M$. piperita growing wild in Eskisehir, Turkey. Therefore, the objective of the present study was to determine the chemical composition, total phenolic content, antioxidant and antimicrobial properties of the essential oil and the extract of $M$. piperita growing wild in Eskisehir.

\section{Material and Methods}

\section{Plant Material}

Mentha $x$ piperita L. were gathered from Mihalliccik, Ucbasli Village/Eskisehir in 24.10.2015 (39 $47^{\prime} 50.5^{\prime \prime} \mathrm{N}$, $\left.31^{\circ} 39^{\prime} 42.8^{\prime \prime} \mathrm{E}\right)$. Identification of the plant was performed by Prof. Dr. Ersin YUCEL. A voucher specimen, No. 18706, was deposited at the herbarium of the ANES (Herbarium of Anadolu University, Eskisehir).

The plant was washed under tap and distilled water, followed by drying on filter paper at room temperature. After drying, the samples were grained in a hammer mill. The materials were stored in tight plastic containers until use.

\section{Production of the Essential Oil and the Extract of the Plant Material}

For the isolation of essential oil, $100 \mathrm{~g}$ of plant material with 2 L of double distilled water was subjected to hydrodistillation for $3 \mathrm{~h}$ in a Clevenger-type apparatus (European
Pharmacopoeia, 1975). The obtained essential oil was held at $4^{\circ} \mathrm{C}$ for further analysis.

For obtaining aqueous extract, powdered samples (20 g) were added distilled water $(100 \mathrm{~L})$ and followed by shaking in a rotary shaker at $220 \times \mathrm{g}$ for $24 \mathrm{~h}$. Then the material was filtered and centrifuged at $5000 \times \mathrm{g}$ for 15 min. The obtained aqueous extracts were kept at $4^{\circ} \mathrm{C}$ for further analysis (Scur et al., 2016).

\section{The Chemical Composition}

Quantification of the chemical constituents was determined using Agilent 7890B GC System equipped with an HP innowax column $(60 \mathrm{~m}$ length $\mathrm{x} 0.25 \mathrm{~mm}$ internal diameter; $0.25 \mu \mathrm{m}$ film thickness) and flame ionization detector (FID) at Anadolu University, Plant, Drug and Scientific Research Application and Research Center, Eskisehir (USP, 1995). The oven temperature was kept at $60^{\circ} \mathrm{C}$ for $10 \mathrm{~min}$ and then increased from $60^{\circ} \mathrm{C}$ to $220^{\circ} \mathrm{C}$ at a rate of $4^{\circ} \mathrm{C} / \mathrm{min}$, held for $10 \mathrm{~min}$ and finally raised to $240^{\circ} \mathrm{C}$ at a rate of $1{ }^{\circ} \mathrm{C} / \mathrm{min}$. The injector and detector temperatures were $250^{\circ} \mathrm{C}$. Helium was used as a carrier gas at $0.7 \mathrm{~mL} / \mathrm{min}$. The sample diluted with hexane (1:10) was injected into the system as $1 \mu \mathrm{L}$ with $40: 1$ split mode.

The constituents were identified by GC-MC Agilent 7890B GC 5977B Mass Selective Detector System equipped with a HP innowax column using the same conditions as in the GC analysis. An electron ionization system with an ionization energy of $70 \mathrm{eV}$ was used over a scan range of 35-450 $\mathrm{m} / \mathrm{z}$ for GC-MS detection and the ion source temperature was $230^{\circ} \mathrm{C}$. The separated constituents were described by National Institute of Standards and Technology (NIST).

\section{Total Phenolic Content}

The total phenolic contents of $M$. piperita essential oil and extract were determined as described by Singleton and Rossi (1965). $2 \mathrm{~g}$ of sample was dissolved in hexane (1 mL) and phenolic compounds were extracted with $1 \mathrm{~mL}$ water:methanol solution (40:60, v/v) for $2 \mathrm{~min}$. Then, the phases were separated by centrifugation at $3500 \mathrm{rpm}$ for 10 min. The hexane phase was re-extracted in the same way. After that, methanolic extracts were diluted with water to a total volume of $2 \mathrm{~mL}$.

$6 \mathrm{~mL}$ of ultra-pure water and $500 \mu \mathrm{L}$ of Folin-Ciocalteu reagent were mixed into a tube, followed by the addition of $100 \mu \mathrm{L}$ methanolic extracts. Then, the mixture was kept at room temperature in the dark for $8 \mathrm{~min}$. $1.5 \mathrm{~mL}$ of $20 \%$ $(\mathrm{w} / \mathrm{v})$ sodium carbonate solution was added to the reaction mixture and the mixture was held at room temperature in the dark for $1 \mathrm{~h}$. The spectrophotometer (Agilent Technologies, Carry60 UV-Visible) was utilized for determining the absorbance of the solution at $765 \mathrm{~nm}$. Standard gallic acid solution was used to construct the calibration curve and the results were stated in $\mu \mathrm{g}$ gallic acid equivalents (GAE)/g dry weight.

\section{Antioxidant Activity}

\section{DPPH Radical Scavenging Activity}

DPPH radical scavenging activity of the samples was evaluated according to the method of Naik et al. (2011). 1 $\mathrm{mL}$ of diluted methanol solutions of the samples (100 $\mu \mathrm{g} / \mathrm{mL}$ ) were mixed with $4 \mathrm{~mL}$ of a methanol solution of 
DPPH (0.1 mM). After keeping the mixture in the dark at room temperature for $30 \mathrm{~min}$, the absorbance was measured at $515 \mathrm{~nm}$ by spectrophotometer. Methanol was used as control. DPPH radical scavenging capacity was calculated by the following Eq 1:

$$
\text { DPPH radical scavenging activity }(\%)=\frac{\mathrm{Ac}-\mathrm{As}}{\mathrm{Ac}} \times 100
$$

Where;

As is the absorbance of the sample

$A c$ is the absorbance of the control.

\section{ABTS Radical Scavenging Activity}

ABTS radical scavenging activity of the samples was determined as described by Re et al. (1999). ABTS ${ }^{+}$stock solution was prepared by mixing ammonium persulfate $(2.45 \mathrm{mM})$ with ABTS solution $(7 \mathrm{mM})$ and the mixture was kept in the dark at room temperature for $16 \mathrm{~h}$. Then, until the absorbance value was measured by the spectrophotometer as $0.70 \pm 0.02$ at $734 \mathrm{~nm}$, the mixture was diluted with ethanol. Prepared $\mathrm{ABTS}^{+}$solution $(3 \mathrm{~mL})$ and ethanolic solution of the samples $(0.3 \mathrm{~mL})$ were mixed. After keeping in the dark at room temperature for $6 \mathrm{~min}$, the absorbance was measured using the spectrophotometer at $734 \mathrm{~nm}$. Ethanol was used as a blank. ABTS+ radical scavenging capacity was calculated using following Eq 2:

$$
\text { ABTS radical scavenging activity }(\%)=\frac{A c-A s}{A c} \times 100
$$

\section{Where;}

As is the absorbance of the sample $A c$ is the absorbance of $\mathrm{ABTS}^{+}$solution.

\section{Antimicrobial Activity}

\section{Bacterial Strains}

The antimicrobial activity of the samples was tested against seven microorganisms, including Bacillus subtilis ATCC 6037, Escherichia coli ATCC 1103, E. coli O157:H7 ATCC 43895, Enterococcus faecalis ATCC 29212, Listeria monocytogenes Scott A, Staphylococcus aureus 6538P and Salmonella Typhimurium NRRL-B4420 that were obtained from the Food Microbiology Research Laboratory, Food Engineering Department, Ege University, Izmir. Firstly, the bacterial strains were cultured on Tryptic Soy Broth (TSB, Oxoid, pH 7.3 \pm 0.2 ) at $37^{\circ} \mathrm{C}$ for $24 \mathrm{~h}$. Then the optimized bacterial cultures, equivalent to 0.5 McFarland (DEN-1 McFarland Densitometer, Grant-bio) turbidity standard, were used in the analyses.

\section{Disc Diffusion Method}

The preliminary antimicrobial activity of the samples was evaluated by the disc diffusion method described by Deng et al. (2014). Mueller Hinton Agar (MHA, Oxoid, pH $7.3 \pm 0.2$ ) plates were supplemented with a bacterial suspension. Paper discs (diameter of $6 \mathrm{~mm}$ ) impregnated $40 \mathrm{mg} / \mathrm{mL}$ of the essential oil or the extract dissolved in dimethyl sulfoxide (DMSO, Merck) were dropped on MHA and the plates were incubated at $37^{\circ} \mathrm{C}$ for $24 \mathrm{~h}$. After the incubation period, the diameter of the inhibition zones was determined using ruler. The paper discs impregnated with $10 \mu \mathrm{g} / \mathrm{mL}$ of antibiotics (ampicillin and gentamycin) and sterile water were used as positive and negative controls, respectively.

\section{Broth Dilution Method}

The minimum inhibitory concentration (MIC) value of the samples was determined by broth dilution method in 96 well "U" type sterile microplates (Deng et al., 2014). Firstly, $100 \mu \mathrm{L}$ of Mueller Hinton Broth (MHB) medium was added to each well, followed by $100 \mu \mathrm{L}$ of essential oil or extract dissolved in DMSO (5\%) added to wells of the first row. Then, two-fold serial dilutions were carried out except for $11^{\text {th }}$ and $12^{\text {th }}$ wells and the final concentrations in the wells were; $10 \%, 5 \%, 2.5 \%, 1.25 \%, 0.625 \%$, $0.313 \%, 0.156 \%, 0.078 \%, 0.039 \%, 0.020 \%$, respectively. $100 \mu \mathrm{L}$ of inoculum were added to wells except for $12^{\text {th }}$ well and the plates were incubated at $37^{\circ} \mathrm{C}$ for $18 \mathrm{~h} .20 \mu \mathrm{L}$ of 0.5\% 2,3,5-triphenyltetrazolium chloride (TTC, Merck) was used as an indicator of the microbial growth. After addition of TTC, the plates were allowed to incubate at $37^{\circ} \mathrm{C}$ for $30 \mathrm{~min}$. MIC was defined as the lowest concentration required to inhibit the visible growth of the test culture (no color formation). Minimum bactericidal concentration (MBC) was also defined as the lowest concentration no growth was observed on MHA.

\section{Statistical Analyses}

Experiments were performed in three replicates. Experimental data were evaluated by one-way ANOVA using the SPSS software version 20 and the means were separated by Independent-sample T-test at the confidence level of 95\% (SPSS, 2011).

\section{Results and Discussion}

\section{Chemical Composition of Mentha $x$ piperita}

In the present study, thirteen constituents were determined in $M$. piperita extract, which represented about $94.5 \%$ of the sample, while fourteen constituents were identified in $M$. piperita essential oil representing $92.3 \%$ of the oil (Table 1). The primary constituent of the essential oil of $M$. piperita was carvone $(55.8 \%)$ and it was followed by limonene $(12.8 \%)$, 1,8-cineole $(8.7 \%)$ and transdihydrocarvone $(6.4 \%)$. However, carvone $(56.4 \%)$, 1,8cineole $(14.1 \%)$ and trans-dihydrocarvone $(8.4 \%)$ were determined as the major compounds of $M$. piperita extract. Similarly, to our findings, carvone (49.27\%) and limonene (37.18\%) were found as the major components of essential oil of M. piperita, grown in Ceará (Brazil), by de Sousa Barros et al. (2015). In another study, the main constituents of $M$. piperita essential oil, collected from Tehran (Iran), were 1,8 -cineole $(28.03 \%)$, carvone $(21.04 \%)$, pulegone $(19.81 \%)$ and dihydrocarvone (18.62\%) (Peyvandi et al., 2016). As in contrast with our results, the main components of essential oil of $M$. piperita, collected from Barij (Saudi Arabia), Jinan (China) and Amazonas (Brazil), were determined as menthol $(36.9 \%, 30.69 \%$ and $33.8 \%)$, menthone $(28.8 \%, 14.51 \%$ and $15.2 \%)$ and menthyl acetate $(4.54 \%, 12.86 \%$ and $13.0 \%)$, respectively (Mahboubi and Kazempour, 2014; Sun et al., 2014; Chagas et al., 2020). In a study conducted by Verma et al. (2011), the chemical compositions of $M$. piperita and $M$. spicata essential oil, obtained from India, were examined. The main 
components of $M$. piperita essential oil were menthol (36.51) and menthone $(29.78 \%)$ while carvone $(52.06 \%)$ and limonene $(22.32 \%)$ were determined as major constituents of essential oil of $M$. spicata. In another study, the major constituents of $M$. piperita essential oil, purchased from a local market in New Delhi (India), were menthol $(26.53 \%)$ and menthone $(25.83 \%)$ while, the main component of $M$. citrata essential oil was determined as linalool acetate $(26.69 \%)$ (Kumar et al., 2012). These studies have demonstrated that the chemical composition of plants might change depending on the plant type and geographical location the plant is grown in.

\section{The Total Phenolic Content and Antioxidant Capacity of Mentha x piperita}

Phenolic compounds are significant substances as radical scavengers, metal chelators, reducing agents, hydrogen donors and singlet oxygen quenchers. Due to the positive effects of phenolic compounds on health, the use of medicinal and aromatic herbs rich in phenolic compounds in food and pharmaceutical products has been increased in recent years (Proestos et al., 2006). Therefore, in the present study, the total phenolic contents of peppermint essential oil and extract were demonstrated as 2204.33 and $744 \mu \mathrm{g}$ GAE/g, respectively (Table 2) $(\mathrm{P}<0.05)$. The findings of Zaidi and Dahiya (2015), who determined the total phenolic contents of $M$. piperita and M. spicata essential oil, grown in Delhi (India), as 12.63 and $9.41 \mu \mathrm{g} \mathrm{GAE} / 5 \mathrm{mg}$, respectively, were consistent with our results. In another study, the total phenolic contents of methanolic extracts of $M$. piperita (La Serena, Chile), dried using a vacuum oven at five different temperatures $(50,60$, 70,80 and $90^{\circ} \mathrm{C}$ ), were found ranging between 11.56 and $27.12 \mathrm{mg}$ GAE$/ \mathrm{g}$, which decreased with the increased drying temperature (Uribe et al., 2016).

The phenolic compounds significantly contribute to the antioxidant capacity of plants. To determine the antioxidant capacity of the plant materials, there are various spectrophotometric methods. In the present study, antioxidant activities of the samples were screened using two different methods. It was determined that, $M$. piperita essential oil and aqueous extract were inhibited $84.08 \%$ and $42.59 \%$ by the DPPH radical, respectively. Besides, the ABTS radical scavenging activity of essential oil and extract were $91.87 \%$ and $48.40 \%$, respectively (Table 2).

As in the total phenolic contents of the samples, the antioxidant capacity of the essential oil was significantly higher than the extract of $M$. piperita $(\mathrm{P}<0.05)$. In a study performed by Singh et al. (2015), it was observed that essential oil and extracts (petroleum ether, chloroform, ethyl acetate, ethanol and aqueous) of $M$. piperita, grown in Benghazi (Libya), inhibited DPPH radical by $92.6 \%$, $71.3 \%, 91.8 \%, 84.9 \%, 74.8 \%$ and $70.3 \%$, respectively. In another study, crude methanolic extracts of $M$. piperita, collected from Sungai Petani (Malaysia), inhibited approximately $60 \%$ of the DPPH radical (Pramila et al., 2012). In another study, ABTS radical scavenging assay was used to determine the antioxidant activity of extracts (ethanol, methanol, aqueous) of $M$. piperita, collected from Mugla (Turkey). It was determined that, the extracts inhibited $79 \%, 26 \%$ and $88 \%$ of the ABTS radical, respectively (Okmen et al., 2017). All these results showed that the extraction method, solvent type and analyze method used affect the antioxidant activities of plants.

The antioxidant activity of plants is also affected by plant properties such as type, composition and concentration of the plant. In a study conducted by Sun et al. (2014), M. piperita essential oil, collected from Jinan (China), at a concentration of $1000 \mu \mathrm{g} / \mathrm{mL}$ inhibited $79.85 \%$ of the DPPH radical. In another study, essential oil of $M$. piperita, grown in Tehran (Iran), at a concentration of $200 \mu \mathrm{g} / \mathrm{mL}$, inhibited $23.46 \%$ of the DPPH radical (Yadegarinia et al., 2006). Although the essential oil concentration used in our study $(100 \mu \mathrm{g} / \mathrm{mL})$ was lower compared to the essential oil concentration used in these studies, the antioxidant activities of $M$. piperita essential oil used in these studies were found lower when compared with our results. In another study, IC values (concentration required to scavenge $50 \%$ of the DPPH free radical) of essential oils of $M$. piperita and $M$. spicata, grown in Diyarbakir (Turkey), were determined as 60.41 and 77.40 $\mu \mathrm{g} / \mathrm{mL}$, respectively (Kizil et al., 2010).

Antioxidants which retard the progress of many chronic diseases as well as lipid peroxidation, could protect the human body from free radicals and reactive oxygen species effects (Gulcin et al., 2006; Gulcin et al., 2010; Sevindik, 2021). However, synthetic antioxidants that are widely used to protect foods against oxidative spoilage in the food industry, could lead to liver damage and carcinogenesis (Roy et al., 2020). Thus, in recent years, the tendency to consume products containing plant components with natural antimicrobial effects has been increased with revealing the role of foods containing chemical substances in diseases (Tajkarimi et al., 2010; Gyawali and Ibrahim, 2014; Calo et al., 2015). The results of the current study demonstrated that the essential oil and extract of peppermint could be used as an alternative to synthetic oxidants.

\section{Diameter Inhibition Zone of Mentha x piperita}

The preliminary antimicrobial activity of essential oil and extract of $M$. piperita were examined against seven bacteria using disc diffusion method. The inhibition effect of $M$. piperita essential oil was higher than extract for all test microorganisms except for $S$. Typhimurium. $M$. piperita essential oil demonstrated inhibitive effect with diameter inhibition zones (DIZ) ranging between 8.5 and $23 \mathrm{~mm}$, depending on test culture used. Besides, the extract of $M$. piperita showed inhibition zones in the range of 6.5 - $11 \mathrm{~mm}$ on test bacteria except for B. subtilis (Table 3). The highest inhibition effect of $M$. piperita essential oil was observed against $S$. aureus $(23 \mathrm{~mm})$.

The antimicrobial activity of peppermint has shown a good correlation with the total phenolic content and antioxidant activity results found in the current study. In a study conducted by Okmen at al. (2017), the inhibition effect of ethanolic, methanolic and aqueous extracts of $M$. piperita, obtained from Mugla (Turkey), was investigated against different Staphylococcus spp. using disc diffusion method. It was determined that, the DIZ values of extracts were ranged between 7 and $21 \mathrm{~mm}$ depending on the test culture. In another study, the inhibition effects of different concentrations $(0.1,1$ and $10 \mu \mathrm{L})$ of $M$. piperita $\mathrm{L}$. essential oil, collected from Benghazi (Libya), were investigated against $S$. aureus, Streptococcus pyogenes, E. coli and $K$. pneumonia by agar diffusion method and the 
most sensitive microorganism was found as S. aureus for all concentrations used (Singh et al., 2015). In a study performed by Tyagi and Malik (2011), essential oil of $M$. piperita (grown in New Delhi/India), showed inhibitive effect on E. coli, Pseudomonas fluorescens, P. aeruginosa, B. subtilis and Candida albicans with DIZ values in the range of 13-22 $\mathrm{mm}$. In another study, antibacterial effects of extracts (ethanol, methanol, ethyl acetate, chloroform, hexane and petroleum ether) of $M$. piperita, grown in India, were examined against $B$. subtilis, Streptococcus pneumonia, S. aureus, E. coli, Proteus vulgaris and Klebsiella pneumonia using agar well diffusion method. DIZ values of the extracts were determined in the range of 2.4-15.3 $\mathrm{mm}$ and the highest inhibition zone was achieved by ethyl acetate extract against B. subtilis (Sujana et al., 2013). The results of the studies showed that the highest DIZ values against $S$. aureus was obtained from the essential oil of $M$. piperita, grown in Eskisehir. In the previous studies, the effect of chemical components of essential oil and extract of peppermint on cell membrane integrity of bacteria has been reported (Oussalah et al., 2006; Veras et al., 2011). The action mechanism of carvone on microorganisms has been associated with the destabilization of the phospholipid bilayer structure and inhibition of enzymes and proteins (Aggarwal et al., 2002)

\section{Minimum Inhibition Concentration and Minimum} Bactericidal Concentration of Mentha $x$ piperita

The MIC values of $M$. piperita essential oil and extract were determined against seven microorganisms using broth dilution method. The MIC values of the essential oil were found ranging between $2.5 \%$ and $10 \%(\mathrm{v} / \mathrm{v})$ (Table 3 ).

Table 1. Chemical composition of extract and essential oil of Mentha x piperita (\%)

\begin{tabular}{l|cc}
\hline \multicolumn{1}{c|}{ Constituents } & Extract & Essential oil \\
\hline Isoamyl alcohol & 0.6 & - \\
1,8-cineole & 14.1 & -7 \\
(Z)-3-hegzen-1-ol & 0.5 & - \\
Trans-sabinene hydrate & 1.5 & - \\
Terpinene-4-ol & 1.1 & 0.6 \\
$\alpha$-pinene & - & 1.4 \\
$\beta$-pinene & - & 0.9 \\
Sabinene & - & 12.8 \\
Limonene & - & 0.8 \\
Myrcene & - & 1.5 \\
$\beta$-bourbonene & - & 2.0 \\
$\beta$-caryophyllene & - & 6.4 \\
Trans-dihydrocarvone & 8.4 & 0.9 \\
Cis-isodihydrocarvone & 2.2 & - \\
$\delta$-terpineol & 1.5 & 1.1 \\
$\alpha$-terpineol & 3.1 & 1.1 \\
Neodihydrocarveol & 1.6 & 55.8 \\
Carvone & 56.4 & 0.5 \\
Karyofillen oxide & - & - \\
Trans-carveol & 0.7 & - \\
Phenyl ethyl alcohol & 0.6 & \\
\hline
\end{tabular}

Table 2. Total phenolic contents and antioxidant activity of extract and essential oil of Mentha x piperita

\begin{tabular}{l|ccc}
\hline \multicolumn{1}{c|}{ M. piperita } & Total phenolic contents $(\mu \mathrm{g} \mathrm{GAE} / \mathrm{g})$ & DPPH $(\%)$ & ABTS $(\%)$ \\
\hline Extract & $744.00 \pm 29.82^{\mathrm{a}}$ & $42.59 \pm 2.27^{\mathrm{a}}$ & $48.40 \pm 1.04^{\mathrm{a}}$ \\
Essential oil & $2204.33 \pm 95.45^{\mathrm{b}}$ & $84.08 \pm 0.12^{\mathrm{b}}$ & $91.87 \pm 0.16^{\mathrm{b}}$ \\
\hline
\end{tabular}

*Values in the same column with different letters (a, b) are significantly different at $\mathrm{P}<0.05$.

Table 3. Antimicrobial activities of extract and essential oil of Mentha x piperita against test microorganisms

\begin{tabular}{|c|c|c|c|c|c|c|c|c|c|}
\hline \multirow{2}{*}{ Test Bacteria } & \multicolumn{2}{|c|}{$\mathrm{MIC}(\mathrm{v} / \mathrm{v}, \%)$} & \multicolumn{2}{|c|}{$\mathrm{MBC}(\mathrm{v} / \mathrm{v}, \%)$} & \multicolumn{5}{|c|}{ Disc diffusion (mm) } \\
\hline & EX & $\mathrm{EO}$ & $\mathrm{EX}$ & EO & EX & $\mathrm{EO}$ & Amp. & Gen. & SW \\
\hline B. subtilis & $>10$ & 10 & $>10$ & 10 & $6 \pm 0$ & $14.5 \pm 0.5$ & $29 \pm 1.0$ & $29.5 \pm 0.5$ & $6 \pm 0$ \\
\hline E. faecalis & 10 & 5 & $>10$ & $>10$ & $7 \pm 1$ & $10 \pm 0$ & $21 \pm 1.0$ & $14.5 \pm 0.5$ & $6 \pm 0$ \\
\hline L. monocytogenes & 10 & 2.5 & $>10$ & $>10$ & $8 \pm 2$ & $11.5 \pm 1.5$ & $28 \pm 2.0$ & $28.5 \pm 1.5$ & $6 \pm 0$ \\
\hline S. aureus & $>10$ & 10 & $>10$ & 10 & $7 \pm 1$ & $23 \pm 3.0$ & $35.5 \pm 0.5$ & $22.5 \pm 0.5$ & $6 \pm 0$ \\
\hline E. coli & $>10$ & 5 & $>10$ & $>10$ & $8.5 \pm 2.5$ & $13 \pm 3.0$ & $20.5 \pm 0.5$ & $21.5 \pm 1.5$ & $6 \pm 0$ \\
\hline E. coli $\mathrm{O} 157: \mathrm{H} 7$ & $>10$ & 5 & $>10$ & $>10$ & $6.5 \pm 0.5$ & $10.5 \pm 0.5$ & $11.5 \pm 0.5$ & $18 \pm 0$ & $6 \pm 0$ \\
\hline S. Typhimurium & $>10$ & 10 & $>10$ & 10 & $11 \pm 1$ & $8.5 \pm 1.5$ & $18 \pm 2.0$ & $20 \pm 0$ & $6 \pm 0$ \\
\hline
\end{tabular}

*EX: Extract; EO: Essential Oil; MIC: Minimum Inhibition Concentration; MBC: Minimum Bactericidal Concentration; Amp.: Ampicillin; Gen.: Gentamycin; SW.: sterile water 
However, M. piperita extract had lower antimicrobial activity $(10 \%$ and $>10 \%)$. The most resistant microorganisms to the essential oil were $B$. subtilis, $S$. aureus and $S$. Typhimurium, while the essential oil demonstrated the highest antibacterial effect on $L$. monocytogenes. On the other hand, essential oil of $M$. piperita showed bactericidal effect at $10 \%$ concentration against $B$. subtilis, $S$. aureus and $S$. Typhimurium, while extract of $M$. piperita did not show bactericidal effect at concentrations under $10 \%$ against any test microorganisms (Table 3).

In a study conducted by Singh et al. (2015), the antimicrobial activity of $M$. piperita essential oil was examined against $S$. aureus, $S$. pyogenes, E. coli and $K$. pneumonia. MIC and MBC values of the essential oil were determined in the range of $0.4 \%-0.7 \%(\mathrm{v} / \mathrm{v})$ and $0.6 \%$ $0.9 \%(\mathrm{v} / \mathrm{v})$, respectively. In another study, it was observed that the MIC and MBC values of $M$. piperita essential oil against Aeromonas spp. were ranged between 2500 and $10000 \mu \mathrm{g} / \mathrm{mL}$ (Chagas et al., 2020). In a study performed by Tyagi and Malik (2011), the antimicrobial effects of $M$. piperita essential oil were investigated against E. coli $\alpha \mathrm{DH} 5$, E. coli ATCC 25922, P. aeruginosa, $P$. fluorescens, B. subtilis, S. aureus, Penicillium digitatum, Aspergillus flavus, A. niger, Mucor spp., Fusarium oxysporum, C. albicans and Sacchromyces cerevisiae. $\mathrm{MIC}$ and $\mathrm{MBC}$ or minimum fungicidal concentration (MFC) values of the essential oil were in the range of 1.13$2.25 \mathrm{mg} / \mathrm{mL}$ and $2.25-9 \mathrm{mg} / \mathrm{mL}$, respectively. In another study, ethanol and methanol extracts of $M$. piperita had MIC values ranging between 3250 and $6500 \mu \mathrm{g} / \mathrm{mL}$ against Staphylococcus spp., while the aqueous extract did not show antimicrobial effect on test cultures (Okmen et al., 2017). These differences could be derived from geographical environment, plant properties, extraction method, test microorganism and analyze method used.

It is stated that the antimicrobial activity of essential oils and extracts is caused by chemical constituents containing hetero atoms such as oxygen and phenolic compounds (Dorman and Deans, 2000; Delaquis et al., 2002; Cueva et al., 2010; Gyawali and Ibrahim, 2014; Reddy and Al-Rajab, 2016). Various studies have reported the strong antimicrobial activity of carvone which has a hydroxyl group around the phenolic ring (Ceylan and Fung, 2004; Neri et al., 2009; Morcia et al., 2012). These groups disrupt the membrane structure of the cells by interacting with the cell membrane of the microorganism and cause the cellular components to leak out of the cell (Xue et al., 2013; Sengun and Ozturk, 2018).

\section{Conclusion}

The present study exhibited that $M$. piperita has significant antioxidant and antimicrobial potentials. It was determined that the main constituent of essential oil and extract was carvone. On the other hand, a significant correlation was observed between the total phenolic contents and antioxidant capacity (DPPH and ABTS). $M$. piperita samples exhibited antimicrobial activity to all test bacteria in various sensitivities, which could be caused by the major components and the total phenolic contents of the essential oil and the extract of $M$. piperita Also, bioactive and antimicrobial properties of the essential oil were higher than of the $M$. piperita extract. All these results showed that essential oil and extract of $M$. piperita could be recommended as antimicrobial and antioxidant agents for the food and pharmaceutical industries. Therefore, further studies should be focused on the use of $M$. piperita essential oil in food applications.

\section{Acknowledgments}

The authors are grateful for the support of Anadolu University, Plant, Drug and Scientific Research Application and Research Center, Eskisehir.

\section{References}

Aggarwal KK, Khanuja SPS, Ahmad A, Kumar TRS, Gupta VK, Kumar S. 2002. Antimicrobial activity profiles of the two enantiomers of limonene and carvone isolated from the oils of Mentha spicata and Anethum sowa. Flavour and Fragrance Journal, 17(1): 59-63. doi: 10.1002/ffj.1040

Bakkali F, Averbeck S, Averbeck D, Idaomar M. 2008. Biological effects of essential oils- a review. Food and Chemical Toxicology, 46: 446-475. doi: 10.1016/j.fct. 2007.09.106

Boskovic M, Zdravkovic N, Ivanovic J, Janjic J, Djordjevic J, Starcevic M, Baltic MZ. 2015. Antimicrobial activity of thyme (Tymus vulgaris) and oregano (Origanum vulgare) essential oils against some food-borne microorganisms. Procedia Food Science, 5: 18-21. doi: 10.1016/j. profoo.2015.09.005

Calo JR, Crandall PG, O'Bryan CA, Ricke SC. 2015. Essential oils as antimicrobials in food systems-A review. Food Control, 54: 111-119. doi: 10.1016/j.foodcont.2014.12.040

Ceylan A, Daniel Y. 2004. Antimicrobial activity of spices. Journal of Rapid Methods \& Automation in Microbiology, 12: 1-55. doi: 10.1111/j.1745-4581.2004.tb00046.x

Chagas EC, Majolo C, Monteiro PC, Oliveira MRD, Gama PE, Bizzo HR, Chaves FCM. 2020. Composition of essential oils of Mentha species and their antimicrobial activity against Aeromonas spp. Journal of Essential Oil Research, 32(2): 209-215. doi: 10.1080/10412905.2020.1741457

Cowan MM. 1999. Plant products as antimicrobial agents. Clinical Microbiology Reviews, 12(4): 564-582. doi: 10.1128/CMR.12.4.564

Cueva C, Moreno-Arribas MV, Martín-Álvarez PJ, Bills G, Vicente MF, Basilio A, Rivas CL, Requena T, Rodríguez JM, Bartolomé B. 2010. Antimicrobial activity of phenolic acids against commensal, probiotic and pathogenic bacteria. Research in Microbiology, 161(5): 372-382. doi: 10.1016/j.resmic.2010.04.006

De Sousa Barros A, de Morais SM, Ferreira PAT, Vieira ÍGP, Craveiro AA, dos Santos Fontenelle RO, de Menezes JESA, da Silva FWF, de Sousa HA. 2015. Chemical composition and functional properties of essential oils from Mentha species. Industrial Crops and Products, 76: 557-564. doi: 10.1016/j.indcrop.2015.07.004

Delaquis PJ, Stanich K, Girard B, Mazza G. 2002. Antimicrobial activity of individual and mixed fractions of dill, cilantro, coriander and eucalyptus essential oils. International Journal of Food Microbiology, 74: 101-109. doi: 10.1016/s01681605(01)00734-6

Deng Y, Yang G, Yue J, Qian B, Liu Z, Wang D, Zhong Y, Zhao Y. 2014. Influences of ripening stages and extracting solvents on the polyphenolic compounds, antimicrobial and antioxidant activities of blueberry leaf extracts. Food Control, 38: 184-191. doi: 10.1016/j.foodcont.2013.10.023

Dorman HD, Deans SG. 2000. Antimicrobial agents from plants: Antibacterial activity of plant volatile oils. Journal of Applied Microbiology, 88(2): 308-316. doi: 10.1046/j.13652672.2000.00969.x 
El-Maati MFA, Mahgoub SA, Labib SM, Al-Gaby AM, Ramadan MF. 2016. Phenolic extracts of clove (Syzygium aromaticum) with novel antioxidant and antibacterial activities. European Journal of Integrative Medicine, 8(4): 494-504. doi: 10.1016/j.eujim.2016.02.006

European Pharmacopoeia 1975. Maissonneuve SA, SainteRuffine.

Grigoleit HG, Grigoleit P. 2005. Peppermint oil in irritable bowel syndrome. Phytomedicine, 12: 601-606. doi: 10.1016/j.phymed.2004.10.005

Gulcin I, Huyut Z, Elmastas M, Aboul-Enein HY. 2010. Radical scavenging and antioxidant activity of tannic acid. Arabian Journal of Chemistry, 3(1): 43-53. doi: 10.1016/j.arabjc.2009.12.008

Gulcin I, Mshvildadze V, Gepdiremen A, Elias R. 2006. Screening of antiradical and antioxidant activity of monodesmosides and crude extract from Leontice smirnowii tuber. Phytomedicine, 13(5): 343-351. doi: 10.1016/j.phymed.2005.03.009

Gyawali R, Ibrahim SA. 2014. Natural products as antimicrobial agents. Food Control, 46: 412-429. doi: 10.1016/j.foodcont. 2014.05.047

Hadian J, Akramian M, Heydari H, Mumivand H, Asghari B. 2012. Composition and in vitro antibacterial activity of essential oils from four Satureja species growing in Iran. Natural Product Research, 26: 98-108. doi: 10.1080/ 14786419.2010.534734

Hayek SA, Gyawali R, Ibrahim SA. 2013. Antimicrobial natural products. Formatex Info, 27: 910-921.

Hinneburg I, Dorman D, Hiltunen R. 2006. Antioxidant activities of extracts from selected culinary herbs and spices. Food Chemistry, 97: 122-129. doi: 10.1016/j.foodchem.2005.03 .028

Inan O, Ozcan MM, Al Juhaimi FY. 2012. Antioxidant effect of mint, laurel and myrtle leaves essential oils on pomegranate kernel, poppy, grape and linseed oils. Journal of Cleaner Production, 27: 151-154. doi: 10.1016/j.jclepro.2012.01.003

Iscan G, Kirimer N, Kürkcüoglu M, Baser HC, Demirci F. 2002. Antimicrobial screening of Mentha piperita essential oils. Journal of Agricultural and Food Chemistry, 50(14): 39433946. doi: 10.1021/jf011476k

Jayasena DD, Jo C. 2013. Essential oils as potential antimicrobial agents in meat and meat products: A review. Trends in Food Science and Technology; 34(2): 96-108. doi: 10.1016/j.tifs. 2013.09.002

Kizil S, Hasimi N, Tolan V, Kilinc E, Yuksel U. 2010. Mineral content, essential oil components and biological activity of two mentha species (M. piperita L., M. spicata L.). Turkish Journal of Field Crops, 15(2): 148-153.

Kumar P, Mishra S, Malik A, Satya S. 2012. Efficacy of Mentha× piperita and Mentha citrata essential oils against housefly, Musca domestica L. Industrial Crops and Products, 39: 106112. doi: 10.1016/j.indcrop.2012.02.021

Lai PK, Roy J. 2004. Antimicrobial and chemopreventive properties of herbs and spices. Current Medicinal Chemistry, 11(11): 1451-1460. doi: 10.2174/0929867043365107

Mahboubi M, Kazempour N. 2014. Chemical composition and antimicrobial activity of peppermint (Mentha piperita L.) essential oil. Songklanakarin Journal of Science and Technology, 36(1): 83-87.

Mohammed FS, Pehlivan M, Sevindik E, Akgul H, Sevindik M, Bozgeyik I, Yumrutas O. 2021. Pharmacological properties of edible Asparagus acutifolius and Asparagus officinalis collected from North Iraq and Turkey (Hatay). Acta Alimentaria, 50(1): 136-143.

Mohammed FS, Şabik AE, Doğan M, Selamoğlu Z, Sevindik M. 2020. Antioxidant potential of Hypericum spectabile JAUB. ET SPACH. Bulletin of Biotechnology, 1(2): 43-45.

Mohammed FS, Karakaş M, Akgül H, Sevindik M. 2019. Medicinal properties of Allium calocephalum collected from Gara Mountain (Iraq). Fresen Environ Bull, 28(10): 7419-7426.
Morcia C, Malnati M, Terzi V. 2012. In vitro antifungal activity of terpinen-4-ol, eugenol, carvone, 1,8-cineole (eucalyptol) and thymol against mycotoxigenic plant pathogens. Food Additives \& Contaminants, 29(3): 415-422. doi: 10.1080/19440049.2011.643458

Naik DG, Dandge CN, Rupanar SV. 2011. Chemical examination and evaluation of antioxidant and antimicrobial activities of essential oil from Gymnema sylvestre R. Br. Leaves. Journal of Essential Oil Research, 23(3): 12-19. doi: 10.1080/10412905.2011.9700451

Neri F, Mari M, Brigati S, Bertolini P. 2009. Control of Neofabraea alba by plant volatile compounds and hot water. Postharvest Biology and Technology, 51: 425-430. doi: 10.1016/j.postharvbio.2008.08.006

Okmen AS, Okmen G, Arslan A, Vurkun M. 2017. Antibacterial activities of Mentha piperita L. extracts against bacteria isolated from soccer player's shoes and its antioxidant activities. Indian Journal of Pharmaceutical Education and Research, 51(3): 163-169. doi: 10.5530/ijper.51.3s.5

Oussalah M, Caillet S, Lacroix M. 2006. Mechanism of action of Spanish oregano, Chinese cinnamon, and savory essential oils against cell membranes and walls of Escherichia coli 0157:57 and Listeria monocytogenes. Journal of Food Protection, 69(5): 1046-1055. doi: 10.4315/0362-028x-69.5.1046

Pehlivan M, Mohammed FS, Şabik AE, Kına E, Dogan M, Yumrutaş Ö, Sevindik M. 2021. Some Biological activities of ethanol extract of Marrubium globosum. Turkish Journal of Agriculture-Food Science and Technology, 9(6): 1129-1132.

Peyvandi M, Aboie Mehrizi Z, Ebrahimzadeh M. 2016. The effect of cadmium on growth and composition of essential oils of Mentha piperita L. Plant Physiology, 6(3): 1715-1720. doi: 10.22034/IJPP.2016.532686

Pramila DM, Xavier R, Marimuthu K, Kathiresan S, Khoo ML, Senthilkumar M, Sathya K, Sreeramanan S. 2012. Phytochemical analysis and antimicrobial potential of methanolic leaf extract of peppermint (Mentha piperita: Lamiaceae). Journal of Medicinal Plants Research, 6(2): 331335. doi: 10.5897/JMPR11

Proestos C, Boziaris IS, Nychas GJE, Komaitis M. 2006. Analysis of flavonoids and phenolic acids in Greek aromatic plants: investigation of their antioxidant capacity and antimicrobial activity. Food Chemistry, 95: 664-671. doi: 10.1016/j.foodchem.2005.01.049

Raut JS, Karuppayil SM. 2014. A status review on the medicinal properties of essential oils. Industrial Crops and Products, 62: 250-264. doi: 10.1016/j.indcrop.2014.05.055

Re R, Pellegrini N, Proteggente A, Pannala A, Yang M, RiceEvans C. 1999. Antioxidant activity applying an improved ABTS radical cation decolorization assay. Free Radical Biology and Medicine, 26: 1231-1237. doi: 10.1016/S08915849(98)00315-3

Reddy DN, Al-Rajab AJ. 2016. Chemical composition, antibacterial and antifungal activities of Ruta graveolens L. volatile oils. Cogent Chemistry, 2(1): 1-11. doi: 10.1080/23312009.2016.1220055

Reyes-Munguía A, Carrillo-Inungaray ML, Carranza-Álvarez C, Pimentel-González DJ, Alvarado-Sánchez B. 2016. Antioxidant activity, antimicrobial and effects in the immune system of plants and fruits extracts. Frontiers in Life Science, 9(2): 90-98. doi: 10.1080/21553769.2015.1104388

Rodriguez-Garcia I, Silva-Espinoza BA, Ortega-Ramirez LA, Leyva JM, Siddiqui MW, Cruz-Valenzuela MR, GonzalezAguilar GA, Ayala-Zavala JF. 2016. Oregano essential oil as an antimicrobial and antioxidant additive in food products. Critical Reviews in Food Science and Nutrition, 56(10): 1717-1727. doi: 10.1080/10408398.2013.800832

Roy M, Sarker A, Azad MAK, Shaheb MR, Hoque MM. 2020. Evaluation of antioxidant and antimicrobial properties of dark red kidney bean (Phaseolus vulgaris) protein hydrolysates. Journal of Food Measurement and Characterization, 14(1): 303-313. doi: 10.1007/s11694-019-00292-4 
Scur MC, Pinto FGS, Pandini JA, Costa WF, Leite CW, Temponi LG. 2016. Antimicrobial and antioxidant activity of essential oil and different plant extracts of Psidium cattleianum Sabine. Brazilian Journal of Biology, 76(1): 101-108. doi: 10.1590/1519-6984.13714

Sengun IY, Ozturk B. 2018. Some natural antimicrobials of plant origin. C-Life Sciences and Biotechnology, 7(2): 256-276. doi: 10.18036/aubtdc.407806

Sevindik M, Akgul H, Pehlivan M, Selamoglu Z. 2017. Determination of therapeutic potential of Mentha longifolia ssp. longifolia. Fresen Environ Bull, 26(7): 4757-4763.

Sevindik M. 2021. Antioxidant and Oxidant Potantials and Element Contents of Chroogomphus rutilus (Agaricomycetes). Mantar Dergisi, 12(1): 29-32.

Shah P, D'Mello P. 2004. A review of medicinal uses and pharmacological effects of Mentha piperita. Natural Product Radiance, 3: 214-221.

Shiwakoti S, Zheljazkov VD, Schlegel V, Cantrell CL. 2016. Growing spearmint, thyme, oregano, and rosemary in Northern Wyoming using plastic tunnels. Industrial Crops and Products, 94: 251-258. doi: 10.1016/j.indcrop.2016. 08.036

Singh R, Shushni MAM, Belkheir A. 2015. Antibacterial and antioxidant activities of Mentha piperita L. Arabian Journal of Chemistry, 8: 322-328. doi: 10.1016/j.arabjc.2011.01.019

Singleton VL, Rossi JA. 1965. Colorimetry of total phenolics with phosphomolybdic-phosphotungstic acid reagents. American Journal of Enology and Viticulture, 16: 144-158.

Sokovic MD, Vukojevic J, Marin PD, Brkic DD, Vajs V, van Griensven LJLD. 2009. Chemical composition of essential oils of Thymus and Mentha species and their antifungal activities. Molecules, 14: 238-249. doi: 10.3390/molecules 14010238

SPSS, 2011. Statistical Package, SPSS for Windows, Ver. 20.0, Chicago.

Sujana P, Sridhar TM, Josthna P, Naidu CV. 2013. Antibacterial activity and phytochemical analysis of Mentha piperita L. (Peppermint)-An important multipurpose medicinal plant. American Journal of Plant Sciences, 4: 77-83. doi: 10.4236/ajps.2013.41012

Sun Z, Wang H, Wang J, Zhou L, Yang P. 2014. Chemical composition and anti-inflammatory, cytotoxic and antioxidant activities of essential oil from leaves of Mentha piperita grown in China. PloS One, 9(12): 1-15. doi: 10.1371/journal.pone.0114767

Tajkarimi MM, Ibrahim SA, Cliver, DO. 2010. Antimicrobial herb and spice compounds in food. Food Control, 21(9): 1199-1218. doi: 10.1016/j.foodcont.2010.02.003

Tiwari BK, Valdramidis, VP, O'Donnell, CP, Muthukumarappan K, Bourke P, Cullen P. 2009. Application of natural antimicrobials for food preservation. Journal of Agricultural and Food Chemistry, 57(14): 5987-6000. doi: $10.1021 / \mathrm{jf} 900668 \mathrm{n}$

Trevisan SCC, Menezes APP, Barbalho SM, Guiguer EL. 2017. Properties of Mentha piperita: a brief review. World Journal of Pharmaceutical and Medical Research, 3(1): 309-313.

Tsai ML, Wu CT, Lin TF, Lin WC, Huang YC, Yang CH. 2013. Chemical composition and biological properties of essential oils of two mint species. Tropical Journal of Pharmaceutical Research, 12(4): 577-582. doi: 10.4314/tjpr.v12i4.20
Tyagi AK, Malik A. 2011. Antimicrobial potential and chemical composition of Mentha piperita oil in liquid and vapour phase against food spoiling microorganisms. Food Control, 22(11): 1707-1714. doi: 10.1016/j.foodcont.2011.04.002

Uribe E, Marín D, Vega-Gálvez A, Quispe-Fuentes I, Rodríguez A. 2016. Assessment of vacuum-dried peppermint (Mentha piperita L.) as a source of natural antioxidants. Food Chemistry, 190: 559-565. doi: 10.1016/j.foodchem. 2015.05.108

USP, 1995. The U.S. Pharmacopeia National Formulary. USP 23 NF 18.

Veras HNH, Campos AR, Rodrigues FFG, Botelho MA, Coutinho HDM, Menezes IRA, daCosta JGM. 2011. Enhancement of the antibiotic activity of erythromycin by volatile compounds of Lippia alba (Mill.) N.E. Brown against Staphylococcus aureus. Pharmacognosy Magazine, 7(28): 334-337. doi: 10.4103/0973-1296.90415

Verma RS, Pandey V, Padalia RC, Saikia D, Krishna B. 2011. Chemical composition and antimicrobial potential of aqueous distillate volatiles of Indian peppermint (Mentha piperita) and spearmint (Mentha spicata). Journal of Herbs, Spices \& Medicinal Plants, 17(3): 258-267. doi: 10.1080/10496475. 2011.591519

Wafa BA, Makni M, Ammar S, Khannous L, Hassana AB, Bouaziz M, Es-Safi NE, Gdoura R. 2017. Antimicrobial effect of the Tunisian Nana variety Punica granatum L. extracts against Salmonella enterica (Serovars Kentucky and Enteritidis) isolated from chicken meat and phenolic composition of its peel extract. International Journal of Food Microbiology, 241: 123-131. doi: 10.1016/j.ijfoodmicro. 2016.10.007

Xue J, Davidson PM, Zhong, Q. 2013. Thymol nanoemulsified by whey protein-maltodextrin conjugates: The enhanced emulsifying capacity and antilisterial properties in milk by propylene glycol. Journal of Agricultural and Food Chemistry, 61(51): 12720-12726. doi: 10.1021/jf4043437

Yadegarinia D, Gachkar L, Rezaei MB, Taghizadeh M, Astaneh SA, Rasooli I. 2006. Biochemical activities of Iranian Mentha piperita L. and Myrtus communis L. essential oils. Phytochemistry, 67(12): 1249-1255. doi: 10.1016/j. phytochem.2006.04.025

Yucel M, Yucel E. 2019. Langmuir, Freundlich, Temkin and Dubinin-Radushkevich isotherms studies removal of silver from aqueous solution by the Mint extract. Biological Diversity and Conservation, 12(3): 119-124. doi: 10.5505/ biodicon.2019.35220

Zaidi S, Dahiya P. 2015. In vitro antimicrobial activity, phytochemical analysis and total phenolic content of essential oil from Mentha spicata and Mentha piperita. International Food Research Journal, 22(6): 2440-2445.

Zhang Y, Liu X, Wang Y, Jiang P, Quek S. 2016. Antibacterial activity and mechanism of cinnamon essential oil against Escherichia coli and Staphylococcus aureus. Food Control, 59: 282-289. doi: 10.1016/j.foodcont.2015.05.032 